\title{
Intermediates Accumulation and Inhibition Sites of Carpropamid in the Melanin Biosynthesis Pathway of Pyricularia oryzae
}

\author{
Yoshio Kurahashi, Yasuo Araki, Taro Kinbara, Rolf Pontzen* \\ and Isamu YAMAGUCHI** \\ Laboratory for Disease Control, Yuki Research Centre, Nihon Bayer Agrochem Co., Ltd., \\ Yuki 307-0001, Japan \\ *Inst. für Pflanzenkrankheiten, PF-F, Bayer AG, D-51368 Leverkusen, Germany \\ **Microbial Toxicology Laboratory, The Institute of Physical and Chemical Research (RIKEN), \\ 2-1 Hirosawa, Wako 351-0106, Japan
}

(Received March 22, 1997; Accepted September 25, 1997)

\begin{abstract}
Carpropamid $\{(1 R S, 3 S R)$-2,2-dichloro- $N$-[1-(4-chlorophenyl)ethyl]-1-ethyl-3-methylcyclopropanecarboxamide $\}$ strongly inhibited pigmentation in shaking culture as well as in agar plate culture of Pyricularia oryzae and Verticillium dahliae. White crystals were isolated from the extract of the cultures of wild type strains of $P$. oryzae and $V$. dahliae treated with carpropamid. Analytical data of the crystals obtained from a spot at $R f 0.36$ on the TLC plates coincided with those of scytalone. A large amount of scytalone and a small amount of vermelone accumulated in the culture treated with $10 \mu \mathrm{g} / \mathrm{ml}$ of carpropamid, while 2-hydroxyjuglone was not detected in these analyses. When scytalone was added to the shaking culture of albino mutants of $P$. oryzae $\left(\mathrm{P}_{2}\right.$-alb), it promptly disappeared from the culture and the culture was pigmented to light brown. But scytalone remained in the culture if treated with carpropamid. Scytalone and vermelone administered beside the colony of $\mathrm{P}_{2}$-alb on the agar plates were converted to black pigments but the pigmentation was inhibited by carpropamid. These results suggest that carpropamid inhibits dehydration of scytalone and vermelone in the fungal melanin biosynthesis.
\end{abstract}

\section{INTRODUCTION}

Carpropamid $\{(1 R S, 3 S R)-2,2$-dichloro- $N$-[1-(4chlorophenyl) ethyl] - 1 - ethyl - 3 - methylcyclopropanecarboxamide $\}$ is a potent protectant of rice plants with systemic and long lasting properties for the control of rice blast disease. Its effect is exhibited not only against leaf but also panicle blast by one shot application of nursery box treatment at a considerably low rate.,2)

Carpropamid affects pigmentation of various plant pathogenic fungi in the plate culture and their colony colors turn brown from black. Hyaline appressoria of Pyricularia oryzae are formed when germinated in the solution with carpropamid at more than $0.1 \mu \mathrm{g} / \mathrm{ml}$, whereas the chemical does not substantially inhibit vegetative growth, spore germination, germ tube elongation and appressorium formation of $P$. oryzae. ${ }^{3)}$ These actions of carpropamid closely resemble those of conven-

Mode of Action of Carpropamid (WIN ${ }^{\circledR}$, KTU 3616), A New Blast Fungicide (part 1) tional melanin biosynthesis inhibitors (MBIs) such as PCBA, ${ }^{4)}$ tricyclazole ${ }^{5)}$ pyroquilon ${ }^{6)}$ and fthalide. ${ }^{7)}$

From the fact that a fungicidal activity in vitro is scarcely observed in spite of excellent blast controlling efficacy in vivo, it could be argued that carpropamid is converted to active metabolites in the treated plants or enhances resistant reactions in plants. However, no active metabolites have been found in the metabolic study in plants. ${ }^{8)}$ On the other hand, carpropamid has a common moiety in its chemical structure with 2,2dichloro-3,3-dimethylcyclopropane carboxylic acid (DDCP), which has been shown to exert a rice blast controlling activity by accentuating a host defense mechanism..$^{9-11)}$ Carpropamid may, therefore, be expected to induce systemic acquired resistance in plants as its mode of action. But our previous studies indicated that carpropamid had a similar property to MBIs and interferes with melanin biosynthesis in susceptible fungi. ${ }^{3)}$ Since melanin biosynthesis is essential for the blast fungus to penetrate into the host epidermis and to exhibit pathogenicity to rice plants, ${ }^{12-15)}$ carpropamid 
was suggested to exert its efficacy on the disease primarily through inhibition of the melanin biosynthesis.

Known MBI fungicides have some similarity in their structures as well as to substrates of reductase in the melanin biosynthesis pathway. However, carpropamid has little resemblance in chemical structure to these MBIs or the precursors of melanin biosynthesis. Thus carpropamid was supposed to have a novel mechanism of action in melanin biosynthesis inhibition, possibly different from that of the conventional MBIs.

This paper deals with action sites of carpropamid in the melanin biosynthesis pathway and we present here the accumulation of intermediates being different from those induced by the known MBIs.

\section{MATERIALS AND METHODS}

\section{Chemicals}

Carpropamid was synthesized by Bayer and Nihon Bayer Agrochem. Tricyclazole was purchased from the market. Scytalone, an intermediate in melanin biosynthesis, was prepared from the culture of Verticillium dahliae brm-1 mutant. ${ }^{16)}$ Another intermediate, 1,8dihydoxynaphthalene (1,8-DHN), was kindly supplied by Mr. Wada at the Yuki Research Centre. Those compounds were dissolved in methanol and diluted with distilled water. A small amount of Tween 20 was added before dilution when necessary for homogeneous dissolution of the chemicals.

\section{Fungi and Culture Methods}

$P$. oryzae $\mathrm{P}_{2}$ (wild type) and $\mathrm{P}_{2}$-alb (albino mutant: 60-2 and IW), $V$. dahliae brm-1 (brown mutant), and $V$. dahliae (wild type strain $\mathrm{Chr} 208$, kindly provided by Mr. Hoshi, Tokyo Agricultural Experimental Station) were used in this study.

Rice blast fungus $\mathrm{P}_{2}$ was cultured with or without carpropamid on potato dextrose agar (PDA) at $25^{\circ} \mathrm{C}$ for 10 days or in $100 \mathrm{ml}$ of liquid medium of potato dextrose (PD) by reciprocal shaking culture at $25^{\circ} \mathrm{C}$ for 5 to 7 days. To the liquid culture, $1 \mathrm{ml}$ of carpropamid methanol solution at $1000 \mu \mathrm{g} / \mathrm{ml}$ was added after $0,1,2,3,4$ or 5 days of culturing. For the cultivation, $1 \mathrm{ml}$ of spore suspension $\left(10^{6} / \mathrm{ml}\right)$ was mixed with $20 \mathrm{ml}$ of PDA at $43^{\circ}$ $\mathrm{C}$ and the inoculated medium was poured into $9 \mathrm{~cm}$ petri dishes or $1 \mathrm{ml}$ of spore suspension at $10^{5}$ spores $/ \mathrm{ml}$ was added to the PD $(100 \mathrm{ml})$ culture flask. $\mathrm{P}_{2}$-alb 60-2 and IW were inoculated with the $4 \mathrm{~mm}$ disc for plate culture. For liquid culture of $\mathrm{P}_{2}$-alb, 5 pieces of the $4 \mathrm{~mm}$ agar disc were inoculated into the liquid medium.

$V$. dahliae brm-1 and Chr 208 were inoculated with the $4 \mathrm{~mm}$ agar disc from their preculture on PDA plates and cultured at $25^{\circ} \mathrm{C}$ for 28 days in the dark.

\section{Characterization of Intermediates}

3.1 Extraction of metabolites from agar plate culture

In order to determine the accumulation of melanin intermediates in the culture, 10 agar plates of $P$. oryzae $\mathrm{P}_{2}$ or $V$. dahliae $\mathrm{Chr} 208$ cultured with carpropamid were homogenized and extracted with $200 \mathrm{ml}$ of $80 \%$ acetone overnight at room temperature. The filtered residue was re-extracted twice with $200 \mathrm{ml}$ of $80 \%$ fresh acetone. The acetone in the combined extracts was evaporated in vacuo, and the aqueous solution was adjusted to $\mathrm{pH} 2$ with $\mathrm{HCl}$ and saturated with $\mathrm{NaCl}$. This was extracted 3 times with $200 \mathrm{ml}$ of ethyl acetate and fractionated. Then the organic layer was concentrated in vacuo to dryness after dehydration with anhydrous $\mathrm{Na}_{2} \mathrm{SO}_{4}$. It was dissolved in a small amount of acetone and applied onto a silica gel column $(25 \mathrm{~mm}$ i.d. $\times 40 \mathrm{~cm}$, silica gel 60 ; Merck), which was eluted with mixed solvent of acetone: $n$-hexane: ethyl acetate (10:30:60). The eluate was dried in vacuo and filled up with $2 \mathrm{ml}$ of methanol. An aliquot of the solution was applied on a TLC plate (silica gel F-254; Merck) and developed with the solvent described above. After development, the spots of metabolites were observed under UV at 254 and $366 \mathrm{~nm}$. For the quantitative analysis of the intermediates, the methanol solution was applied to HPLC (HP-1090) on LiChrospher $100 \mathrm{RP}-18(4 \mathrm{~mm}$ i.d. $\times 25 \mathrm{~cm})$ at $40^{\circ} \mathrm{C}$ and eluted with acetonitrile- $\mathrm{H}_{2} \mathrm{O}(1 \mathrm{ml} / \mathrm{min}$ : gradient from $10-50 \%$ of acetonitrile $/ 30 \mathrm{~min}$ ).

\subsection{Extraction of metabolites from PD liquid culture}

The filtrate of the liquid culture of $P$. oryzae was extracted three times with an equivalent volume of ethyl acetate after the $\mathrm{pH}$ was adjusted to 2 with $\mathrm{HCl}$. The organic layer was dehydrated with anhydrous $\mathrm{Na}_{2} \mathrm{SO}_{4}$ and dried in vacuo. Subsequent procedures for the analysis were the same as those for the PDA culture.

\section{Crystallization and Identification of the Intermedi- ates}

A large spot on the silica gel TLC was scraped off from the TLC plate and extracted with $20 \mathrm{ml}$ of diethyl ether. An equal volume of $n$-hexane was added to the ether solution and the mixture in the flask was kept in a draft chamber without a cap. With gentle evaporation of ether, a white substance was crystallized in the solution. The crystals were analyzed for melting point, IR, MS, NMR and optical rotation.

\section{Scytalone Metabolism by $P_{2}$-alb and Melanization Recovery by Addition of Intermediates}

One milliliter of scytalone methanol solution at 1000 $\mu \mathrm{g} / \mathrm{ml}$ with or without carpropamid $(1000 \mu \mathrm{g} / \mathrm{ml})$ was added to $100 \mathrm{ml}$ of $\mathrm{P}_{2}$-alb culture. The $\mathrm{P}_{2}$-alb 60-2 and IW were cultured in PD for 3 days prior to scytalone and carpropamid treatment. The remaining scytalone in the 
culture was quantitatively measured at different times.

$\mathrm{P}_{2}$-alb 60-2 was cultured for 4 days on PDA plates amended with carpropamid or tricyclazole at $10 \mu \mathrm{g} / \mathrm{ml}$. Four millimeter filter paper containing $10-30 \mu \mathrm{g}$ of scytalone, vermelone or $1,8-\mathrm{DHN}$ was put beside the albino colony. After 2 days culturing, pigmentation between the colony and the filter paper was observed and assessed.

\section{RESULTS}

\section{TLC Study}

A large clear spot and a small spot were respectively observed at $R f 0.36$ and 0.54 on the TLC plate under UV irradiation at 254 and $366 \mathrm{~nm}$ in the extracts of agar plate culture of rice blast fungus $\mathrm{P}_{2}$ and $V$. dahliae Chr-208 treated with carpropamid. The $R f$ values coincided well with those of authentic scytalone and vermelone, respectively. The spots were hardly seen in the extracts of untreated $P_{2}$ blast culture. In the culture with tricyclazole, pink and yellow-red spots were observed at $R f 0.05$ and 0.02 , which were assumed to be those of flaviolin and 2-hydroxyjuglone (2-HJ), respectively. But these spots were not observed in the culture treated with carpropamid.

In the PD liquid culture of $\mathrm{P}_{2}$ amended with carpropamid, the spot at $R f 0.36$ was also evidently seen on TLC. Another spot, which is thought to be vermelone, was also observed at $R f 0.54$ in the extract of liquid medium treated with carpropamid especially at the later stage of the culture. Thus scytalone was supposed to be abundantly accumulated in the cultures of rice blast fungus and $V$. dahliae treated with carpropamid as in the

Table 1 Identification of isolated crystals.

\begin{tabular}{|c|c|c|}
\hline & Scytalone ${ }^{18)}$ & $\begin{array}{l}\text { Isolated } \\
\text { crystals }\end{array}$ \\
\hline \multirow[t]{2}{*}{ m.p. } & $164-168^{\circ} \mathrm{C}$ & $159-161^{\circ} \mathrm{C}$ \\
\hline & $(95 \% \mathrm{EtOH})$ & (n-Hex/Et-Ether) \\
\hline$[\alpha]_{\mathrm{D}}$ & +32 & $+2-4$ \\
\hline IR & $(\mathrm{KBr}) 1635,1592$ & $(\mathrm{KBr}) 1639,1593$ \\
\hline$\nu_{\max }$ & 1275,1175 & 1273,1174 \\
\hline MS & (probe $80^{\circ} \mathrm{C}$ ) & (probe $80^{\circ} \mathrm{C}$ ) \\
\hline \multirow[t]{5}{*}{$m / z(\%)$} & $194\left(\mathrm{M}^{+} ; 89 \%\right)$ & $194(92 \%)$ \\
\hline & $176\left(\mathrm{M}-\mathrm{H}_{2} \mathrm{O} ; 85\right)$ & $176(81)$ \\
\hline & $15\left(\mathrm{M}-\mathrm{CH}_{2}=\mathrm{CHOH} ; 100\right)$ & $150(100)$ \\
\hline & $122\left(\mathrm{M}-\mathrm{CH}_{2}=\mathrm{CHOH}, \mathrm{CO} ; 26\right)$ & $122(17)$ \\
\hline & $69(35)$ & $69(33)$ \\
\hline \multirow[t]{7}{*}{ H-NMR } & (Acetone- $\mathrm{D}_{6}$ ) & (Acetone- $\mathrm{D}_{6}$ ) \\
\hline & $2.6-3.2(4 \mathrm{H}, \mathrm{m})$ & $2.6-3.2(4 \mathrm{H}, \mathrm{m})$ \\
\hline & $4.2(1 \mathrm{H}, \mathrm{m})$ & $\begin{array}{c}4.2\left(1 \mathrm{H}, \mathrm{m}, \mathrm{D}_{2} \mathrm{O} \mathrm{Ex}\right) \\
4.3(1 \mathrm{H}, \mathrm{m})\end{array}$ \\
\hline & $6.04(1 \mathrm{H}, \mathrm{d}, J=2.5 \mathrm{~Hz})$ & $6.2(1 \mathrm{H}, \mathrm{d}, J=2.2 \mathrm{~Hz})$ \\
\hline & $6.15(1 \mathrm{H}, \mathrm{dd}, J=2.5 \mathrm{~Hz})$ & $6.3(1 \mathrm{H}, \mathrm{m})$ \\
\hline & & $9.4\left(1 \mathrm{H}\right.$, br. s, $\left.\mathrm{D}_{2} \mathrm{O} \mathrm{Ex}\right)$ \\
\hline & $12.45\left(1 \mathrm{H}, \mathrm{s}, \mathrm{D}_{2} \mathrm{O} \mathrm{Ex}\right)$ & $12.8\left(1 \mathrm{H}, \mathrm{s}, \mathrm{D}_{2} \mathrm{O} \mathrm{Ex}\right)$ \\
\hline
\end{tabular}

culture of the brown mutant of $V$. dahliae. On the other hand, 2-HJ, a shunt product related to melanin biosynthesis, was not detected in the culture treated with carpropamid.

\section{Analysis of the Crystals}

Physical and chemical properties of the white crystals isolated from the culture broth were compared with those of scytalone isolated from $V$. dahliae brm-1. ${ }^{17)}$ The results of the analyses are summarized in Table 1 . The melting point, IR and MS data of the crystals were very similar to those of scytalone reported by Bell et al. ${ }^{17}$ ) Optical rotation, however, did not coincide with each other; optical rotation of scytalone isolated from brm-1 was reported to be $\left.(+) 32,{ }^{17}\right)$ but the crystals isolated from wild types of $P$. oryzae $\mathrm{P}_{2}$ and $V$. dahliae $\mathrm{Chr} 208$ as well as the crystals from $V$. dahliae brm-1 showed the optical rotation at $(+) 2-4$ in our measurement. This result suggests that carpropamid did not influence the optical rotation of the crystals. However, the reason why the data of optical rotation were not identical is not clear at present.

\section{Quantitative Study of Scytalone and Vermelone Accumulation}

When carpropamid was added to the liquid culture of $P$. oryzae after 3-day preculture, fresh weight of the mycelia in 5-day culture was hardly influenced by application of carpropamid at 2.5 to $50 \mu \mathrm{g} / \mathrm{ml}$ and each weight was around $750 \mathrm{mg}$ in $100 \mathrm{ml}$ of the culture broth.

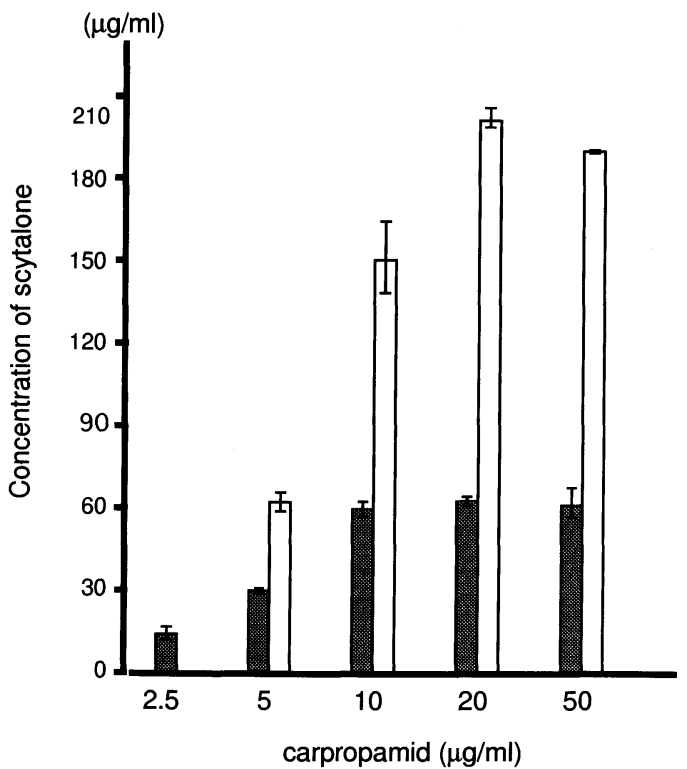

Fig. 1 Accumulation of scytalone in the culture broth treated with carpropamid at $2.5-50 \mu \mathrm{g} / \mathrm{ml}$.

: 5-day culture treated at 3-day preculture, $\square: 6$-day culture treated at 4-day preculture. 


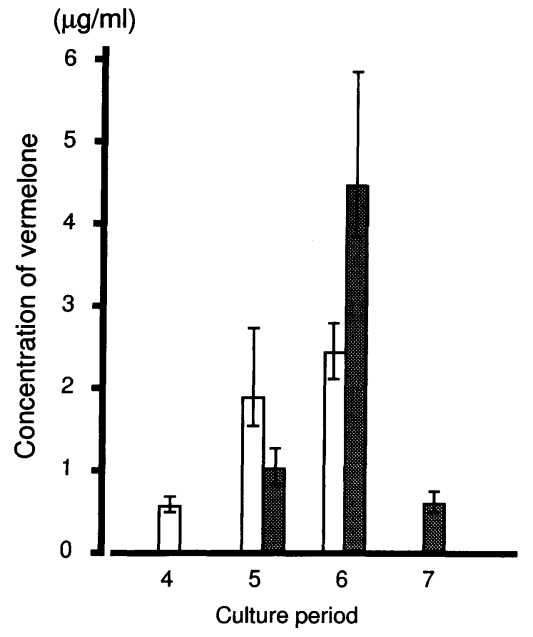

Fig. 2 Accumulation of vermelone in the blast culture treated with carpropamid at $10 \mu \mathrm{g} / \mathrm{ml}$.

$\square$ : 4 to 6 -day culture treated at 3-day preculture, to 7-day culture treated at 4-day preculture.

Scytalone extracted from the culture showed a large peak at Rt 8.0 min on HPLC and the characteristic UV spectrum with $\lambda_{\max }^{\mathrm{EtOH}} 280 \mathrm{~nm}$ was observed. In 5-day culture, amounts of scytalone in the broth increased as the treated concentrations (from 2.5 to $10 \mu \mathrm{g} / \mathrm{ml}$ ), and reached a maximum around $60-80 \mu \mathrm{g} / \mathrm{ml}$. Further accumulation was not observed by the treatment at more than $10 \mu \mathrm{g} / \mathrm{ml}$ of carpropamid after 3-day preculture. The accumulation in the 5-day culture was relatively low when blast inoculation and the chemical treatment were made simultaneously. In the 6-day culture the accumulation of scytalone exceeded $200 \mu \mathrm{g} / \mathrm{ml}$ and reached its maximum when carpropamid was added to the 4-day preculture (Fig. 1). In the 7-day culture, however, the accumulation decreased when the carpropamid was added to the 4-day preculture.

Vermelone was also detected in the culture broth by HPLC analysis. The peak at $R t 14.0 \mathrm{~min}$ and its characteristic UV spectrum with $\lambda_{\max }^{\text {EtoH }} 259$ and $333.5 \mathrm{~nm}$ were identical with those of the authentic sample. The accumulation in the blast culture changed according to the application doses and administration timing of carpropamid to the culture; in 6-day culture $1.7 \mu \mathrm{g} / \mathrm{ml}$ of vermelone was detected when $5 \mu \mathrm{g} / \mathrm{ml}$ of carpropamid was added and 3 to $4 \mu \mathrm{g} / \mathrm{ml}$ accumulated when 10 to 50 $\mu \mathrm{g} / \mathrm{ml}$ was added to 4-day preculture. As shown in Fig. 2 , in 4 to 6 day-culture about $0.6-2.5 \mu \mathrm{g} / \mathrm{ml}$ of vermelone accumulated in the broth when the chemical at $10 \mu \mathrm{g} / \mathrm{ml}$ was added to the culture after 3-day preculture, but vermelone accumulation reached $4.5 \mu \mathrm{g} / \mathrm{ml}$ when added after 4-day preculture.

Thus the application rate and timing of carpropamid to the liquid culture of $P$. oryzae proved to markedly influence scytalone and vermelone accumulation.

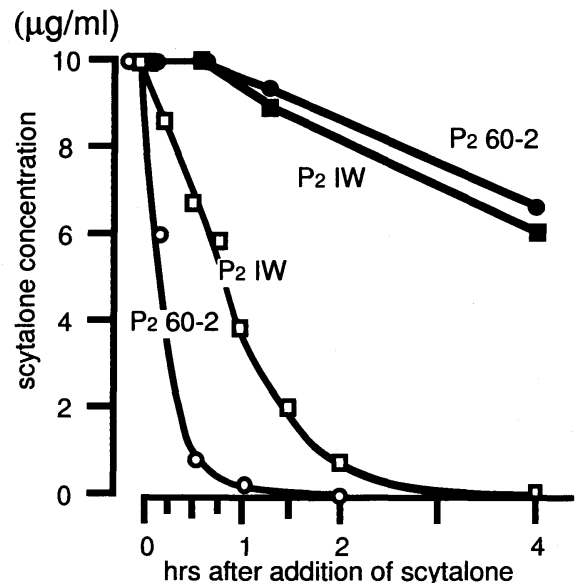

Fig. 3 Effect of carpropamid on scytalone metabolism in the culture of $\mathrm{P}_{2}$-alb 60-2 and IW.

$\bigcirc, \square$ : without carpropamid; $\mathbf{\square}$ : with carpropamid at $10 \mu \mathrm{g} / \mathrm{ml}$.

Table 2 Pigmentation from scytalone and vermelone on plate culture of $\mathrm{P}_{2}$ alb 60-2 and IW.

\begin{tabular}{llcc}
\hline \multirow{2}{*}{ Compound $^{\text {a) }}$} & \multicolumn{3}{c}{ Color of pigmentation } \\
\cline { 2 - 4 } & Scytalone $^{\text {b) }}$ & Vermelone $^{\text {b) }}$ & 1.8-DHN \\
\hline Carpropamid & None & None & Black \\
Tricyclazole & Brown & Black & Black \\
Untreated & Black & Black & Black \\
\hline
\end{tabular}

a) PDA was amended with $10 \mu \mathrm{g} / \mathrm{ml}$ of carpropamid or tricyclazole.

b) Melanin intermediates were topically administered at the edge of the colony.

\section{Metabolism of Scytalone in the Culture of the Albino Strain}

Scytalone externally added to the blast culture was easily metabolized by albino blast strains $\mathrm{P}_{2}$-alb (60-2 \& IW). Scytalone added to the 3-day culture was metabolized to give $50 \%$ residue within 20 to $50 \mathrm{~min}$ and almost completely disappeared in 2 to $4 \mathrm{hr}$ and the culture broth slightly turned to light brown. But most scytalone was re-isolated from the broth without being metabolized in the culture when carpropamid was applied in advance or simultaneously (Fig. 3).

\section{Recovery of Melanization by Scytalone and Ver- melone in the Albino Blast Culture}

Scytalone and vermelone administered beside the albino blast colony were readily converted to black pigment (Table 2). This suggests that melanin biosynthesis enzyme worked in the culture and melanin was synthesized from scytalone and vermelone. However, the pigmentation was strongly inhibited in the culture medium amended with carpropamid. The pigmentation was also observed in the culture of the wild type of blast 


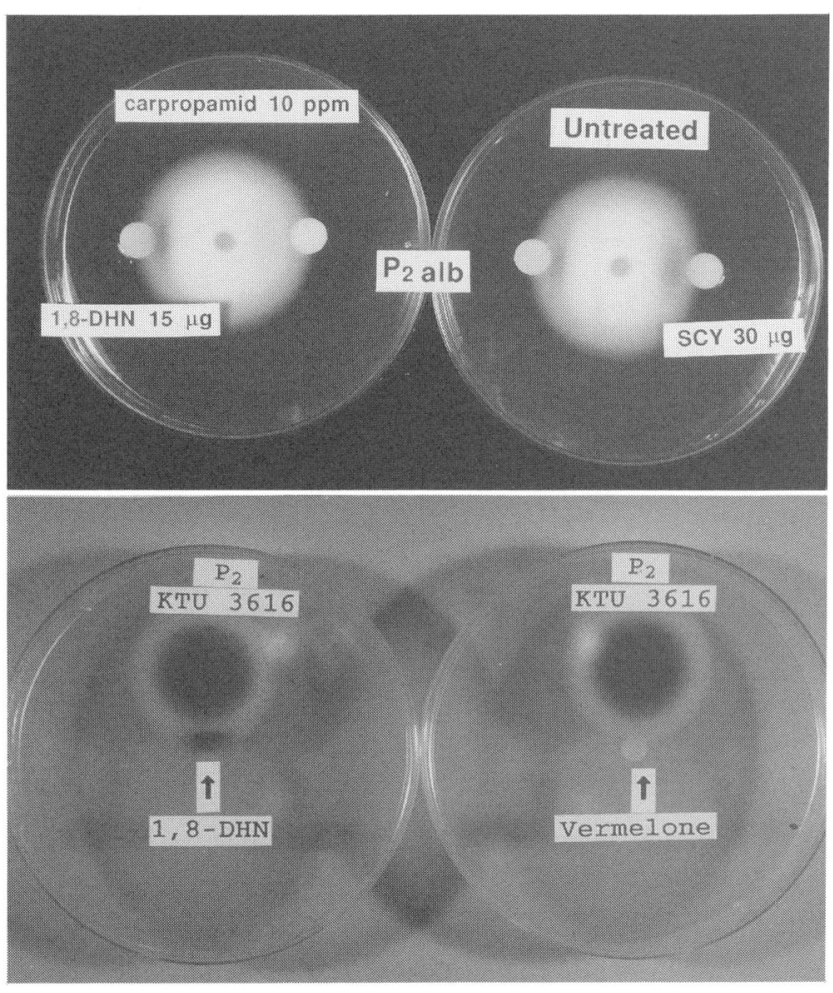

Fig. 4 Melanization from scytalone and vermelone in blast culture plate.

PDA plate was amended with or without carpropamid at 10 $\mu \mathrm{g} / \mathrm{ml}$. Upper picture: the left and right paper disks in the plate contain 1,8-DHN and scytalone, respectively. Lower picture: 1,8-DHN (left) and vermelone (right) contained in paper disks were administered beside blast colony in the plates amended with carpropamid.

fungus $\mathbf{P}_{2}$ but changing of the color was not clear due to the presence of its own pigment in the culture. Carpropamid and tricyclazole did not inhibit the pigmentation from 1,8-DHN.

\section{DISCUSSION}

The present study proved that carpropamid interfered with the biosynthesis of DHN melanin in P. oryzae and $V$. dahliae. Scytalone was predominantly isolated from the culture of $P$. oryzae and $V$. dahliae treated with carpropamid. Tricyclazole and pyroquilon were reported to inhibit the melanization and to induce accumulation of scytalone and $2-\mathrm{HJ}$ as the result of the action. ${ }^{13,18-20)}$ Yamaguchi et al. showed this accumulation of scytalone and 2-HJ in the culture with four MBI fungicides which primarily block the reaction from 1,3,8-trihydroxynaphthalene $(1,3,8$-THN) to vermelone. ${ }^{13)}$ The precursor, 1,3,8-THN, once accumulated in the culture, appears to be easily converted to $2-\mathrm{HJ}$ in the branched pathway. In the culture with carpropamid, a relatively high amount of scytalone accumulates in the culture but 2 -HJ and 1,3,8-THN were not detected by TLC and HPLC analyses. From these data carpropamid is supposed not to block 1,3,8-THN reductase but specifically inhibit scytalone dehydratase. In addition, a small amount of vermelone was detected in the liquid blast culture treated with the carpropamid.

Carpropamid did not show strong influence on blast mycelial growth and there was little difference in the fresh weights of the mycelia treated or not. However, the amounts of scytalone and vermelone in the culture broth increased in parallel by the application of carpropamid and reached a maximum by the treatment at more than 10 $\mu \mathrm{g} / \mathrm{ml}$ in 5-day culture broth. This means that inhibition activity of carpropamid against the two dehydration steps may be in the same level. Culture periods and application timing influenced accumulation of scytalone and vermelone. In 5 to 6-day culture the amount gradually increased from 0 day (inoculated and treated simultaneously) to 4-day preculture and maximum accumulation of scytalone was found at 4-day preculture in 6-day culture. As accumulation of the scytalone and vermelone was not larger in amount by earlier application of the chemical than 3 to 4 -day preculture, it is assumed that carpropamid may interfere with the earlier steps than scytalone dehydration in melanin biosynthesis or to synthesis of the dehydratase. In our experiments, however, flaviolin, which accumulates in the culture treated with tricyclazole or pyroquilon, ${ }^{13,22,23)}$ has never been detected in the culture with carpropamid.

Vermelone proved to accumulate in the blast culture by the treatment of carpropamid $(10 \mu \mathrm{g} / \mathrm{ml})$, as shown in Fig. 2. This might have occurred due to the imperfect inhibition of scytalone dehydration by carpropamid to allow transformation from leaking 1,3,8-THN to vermelone. However, the results that scytalone accumulation reaches the maximum by the treatment of $10 \mu \mathrm{g} / \mathrm{ml}$ carpropamid and that vermelone accumulates more significantly when the chemical is treated at the later stage of the blast culture suggest that existing 1,3,8-THN already formed in the culture is reduced to vermelone but dehydration of vermelone was inhibited by carpropamid. This is supported by the fact that vermelone is detected even in the untreated blast culture. ${ }^{13)}$

In the shaking culture of the albino mutants $\left(\mathrm{P}_{2}\right.$-alb IW and $\mathrm{P}_{2}$-alb 60-2), scytalone added to the culture completely disappeared in a short time and the medium was slightly pigmented to light brown. This means that melanin synthesis ability from scytalone fulfills the function in the albino strains. The metabolism was significantly inhibited by carpropamid and scytalone added to the culture remained in the medium. This suggests that carpropamid specifically inhibits scytalone dehydration process in the melanin biosynthesis.

In addition, scytalone, vermelone and 1,8-DHN were easily converted to black pigment when they were fed at the edge of the colony of the albino mutants. Car- 


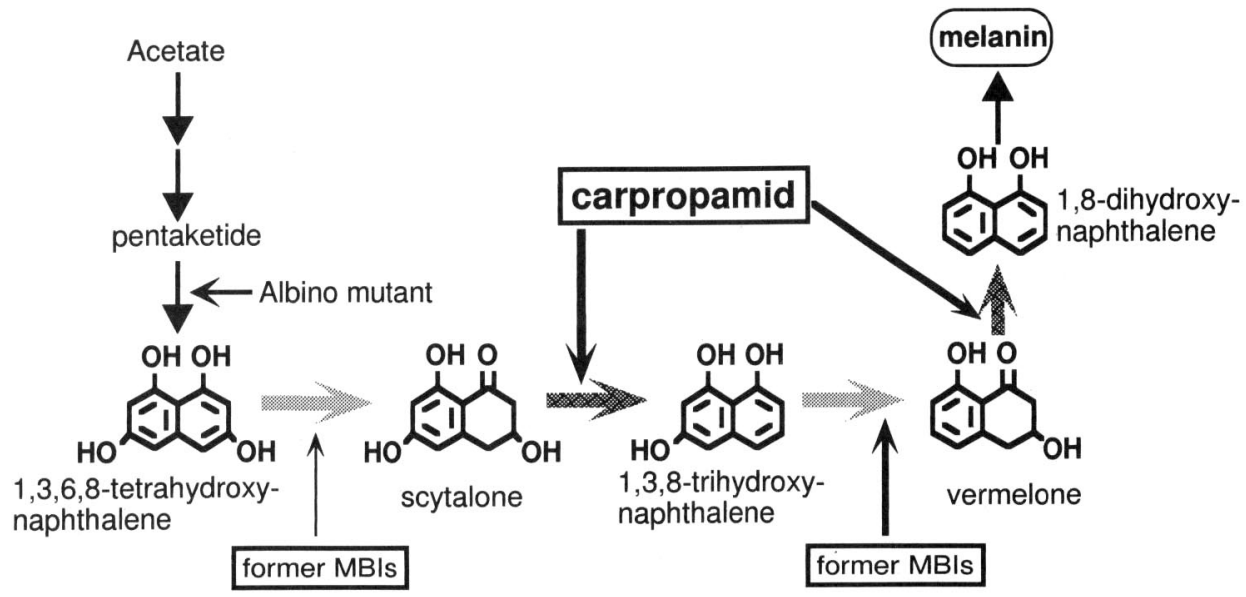

Fig. 5 Inhibition sites of carpropamid in fungal melanin biosynthesis pathway.

$\rightarrow$, dehydration; $\rightarrow$, reduction.

propamid effectively inhibited the metabolism from scytalone and vermelone, but the conversion of 1,8-DHN to black pigment was not inhibited by the chemical. In other words, dehydration of scytalone and vermelone is blocked by carpropamid but polymerization of 1,8-DHN is not affected by the chemical. These results indicate that the action site of carpropamid is not the reduction process from 1,3,8-THN to vermelone but dehydration from scytalone to 1,3,8-THN and from vermelone to 1,8-DHN in the melanin biosynthesis pathway (Fig. 5).

As shown in Fig. 5 there are two reduction and two dehydration steps in the DHN melanin biosynthesis pathway. ${ }^{19,21)}$ Phthalazine derivatives, which were designed on the basis of the stereochemistry of 1,3,8-THN and the known MBIs, were shown to act as a reductase inhibitor and to afford a good effect against rice blast. ${ }^{24)}$ The substrates and reductase inhibitors have some similarity in their chemical structures. But a resemblance between carpropamid and scytalone can hardly be seen in their chemical structures. Carpropamid may be inferred, therefore, to have a different inhibition mechanism from conventional MBIs.

As to blast appressorial penetration, two mechanisms are suggested, i.e. enzymatic and physical penetration into rice epidermis. In fact, activity of such enzymes as cutinase and cellulase concerning metabolism of plant epidermal constituents were found in the culture of various fungi. ${ }^{22,26)}$ The role of melanin in blast appressoria is suggested to induce the rigidity of cell wall to resist an increase of the inner osmotic pressure of the organ generated for penetration into host plant epidermis and to determine the direction of development of penetration peg. ${ }^{12,14,25)}$ Kubo et al. reported a lateral germination from unmelanized appressoria of Colletotrichum lagenarium treated with tricyclazole and then suggested that infection hyphae to be formed vertically in the melanized appressoria has lost the direction due to the insufficient rigidity. ${ }^{27-29)}$ The rise of the pressure in blast appressoria have been measured by Howard et al. and estimated to be as high as $8.0 \mathrm{MPa}{ }^{30,31)}$ But it is thought that the melanin layer in appressorial cells not only works for producing rigidity of the wall but also blocks the efflux of any larger molecule by reducing porosity of the membrane and generates the internal pressure by influx of water caused by osmotic gradient. ${ }^{30-32)}$

Melanin biosynthesis inhibition by carpropamid in the appressoria is supposed primarily to cause the penetration failure because of insufficient rigidity of the cell wall or an unsatisfactory rise of turgor pressure in the cells. On the other hand, the melanization of appressoria of albino mutants and unmelanized appressoria of wild type strains treated with MBIs is relatively easily restored by administration of vermelone and 1,8-DHN but the penetration into epidermal cells is less recovered. Chida and Sisler showed that restoration of penetration into onion epidermis from the unmelanized appressorium in which toxic intermediates such as scytalone and $2-\mathrm{HJ}$ are not accumulated by the action of cerullenin, increased at relatively high rates. ${ }^{15,33)}$ Accumulation of scytalone and vermelone induced by carpropamid may hinder secondarily the appressorium function for their infection since these intermediates accumulated in the blast cell reportedly exert some cell toxicity. ${ }^{13,22)}$

Reductase inhibitors of melanin biosynthesis such as tricyclazole, pyroquilon and fthalide have been developed and practically used for rice blast control. Although the chemicals with dehydratase inhibitory activity on melanin biosynthesis have been predicted, carpropamid is the first one to have been found out as a blast controller with inhibitory activity on the dehydration step in the fungal melanin biosynthesis. In fact, carpropamid can provide an excellent effect against rice 
blast disease by one shot application as nursery box treatment.

Recently a few patents by Sumitomo Chem. Ind. Co. Ltd., ${ }^{34)}$ Kumiai Chem. Ind. Co. Ltd. ${ }^{35)}$ and Rhone Poulenc Co. Ltd ${ }^{36)}$ have been applied for, and similar biological properties were reported on the compounds. They may have the same mode of action as carpropamid because these have a common moiety in their chemical structure with carpropamid.

\section{ACKNOWLEDGMENT}

The authors express their gratitude to Mr. Stubauer and Mr. Yasui for their advice for the work, and to Dr. Kurogochi and Mr. Wada for their assistance with the chemical analysis study. We also thank members of the Chemical Research and Lab. for Disease Control and the late Mr. Hattori for support of this research.

\section{REFERENCES}

1) T. Hattori, Y. Kurahashi, T. Konze \& S. Kagabu: Brighton Crop Protect. Conf. Proc. 2, 517 (1994)

2) Y. Kurahashi: Nouyaku Kenkyu 42 (4), 60 (1996) (in Japanese)

3) Y. Kurahashi, S. Sakawa, T. Kinbara, K. Tanaka \& S. Kagabu: J. Pesticide Sci. 22, 112 (1997)

4) M. Ishida, H. Sumi \& H. Oku: Residue Rev. 25139 (1969)

5) J. D. Froyd, C. J. Paget, L. R. Guse, B. A. Dreikorn \& J. L. Pafford: Phytopathology 66, 1135 (1976)

6) F. Schwinn, M. Nakamura \& Handschin: Int. Congr. Plant Protect., 9th Abstracts, 479, 1979

7) M. Ishida \& K. Nambu: Nouyaku Kagaku 3, 10 (1975) (in Japanese)

8) Internal Report of Yuki Research Centre/NBA (not published)

9) P. Langcake \& S. G. A. Wickings: Physiol. Plant Pathol. 7, 113 (1975)

10) D. W. Cartwright, P. Langcake, R. J. Pryce, D. P. Leworthy \& J. P. Ride: Nature 267, 511 (1977)

11) D. W. Cartwright, P. Langcake \& J. P. Ride: Physiol. Plant Pathol. 17, 259 (1980)

12) C. P. Woloshuk, H. D. Sisler \& E. L. Vigil: Physiol. Plant Pathol. 22, 245 (1983)

13) I. Yamaguchi, S. Sekido \& T. Misato: J. Pesticide Sci. 7, 523 (1982)

14) R. J. Howard \& M. A. Ferrari: Exp. Mycol. 13, 403 (1989)

15) T. Chida \& H. D. Sisler: J. Pesticide Sci. 12, 49 (1987)

16) A. A. Bell, J. E. Puhalla, W. J. Tolmsoff \& R. D. Stipanovic: Can. J. Microbiol. 22, 787 (1976)

17) A. A. Bell, R. D. Stipanovic \& J. E. Puhalla: Tetrahedron 32, 1353 (1976)

18) M. C. Tokousbalides \& H. D. Sisler: Pestic. Biochem. Physiol. 8, 26 (1978)

19) C. P. Woloshuk, H. D. Sisler, M. C. Tokousbalides \& S. R. Dutky: Pestic. Biochem. Physiol. 14, 256 (1980)

20) C. P. Woloshuk \& H. D. Sisler: J. Pesticide Sci. 7161 (1982)

21) R. D. Stipanovic \& A. A. Bell: J. Org. Chem. 41 (No. 14),
2468 (1976)

22) I. Yamaguchi, S. Sekido \& T. Misato: J. Pesticide Sci. 8229 (1983)

23) M. C. Tokousbalides \& H. D. Sisler: Pestic. Biochem. Physiol. 11, 64 (1979)

24) K. Omata, T. Tomita, T. Nakajima \& B. Natsume: Pestic. Sci. 26, 271 (1989).

25) P. M. Wolkow, H. D. Sisler \& E. L. Vigil: Physiol. Plant Pathol. 22, 55 (1983)

26) I. Miura, T. Kamakura, S. Maeno, S. Hayashi \& I. Yamaguchi: Pestic. Biochem. Physiol. 48, 222 (1994)

27) Y. Kubo, K. Suzuki, I. Furusawa, N. Ishida \& M. Yamamoto: Phytopathology 72, 498 (1982)

28) Y. Kubo, K. Suzuki, I. Furusawa \& M. Yamamoto: Phytopathology 72, 1198 (1982)

29) Y. Kubo, K. Suzuki, I. Furusawa \& M. Yamamoto: Pestic. Biochem. Physiol. 23, 47 (1985)

30) R. J. Howard, M. A. Ferrari, D. H. Roach \& N. P. Money: Proc. Natl. Acad. Sci. USA 88, 11281 (1991)

31) N. P. Money \& R. J. Howard: Fungal Genet. Biol. 20, 217 (1996)

32) N. J. Talbot: Trends Microbiol. 3, 9 (1995)

33) T. Chida \& H. D. Sisler: Pestic. Biochem. Physiol. 29, 244 (1987)

34) A. Manabe, M. Mizutani, K. Maeda \& H. Takano: JP-A 3-86855 (1991) (in Japanese)

35) F. Yoshida, S. Ito, K. Tada, K. Eguchi \& S. Hayashi: JP-A 6-157499 (1994) (in Japanese)

36) N. Sasaki, N. Sotojima, Y. Kirio, B. Milligan \& N. Sawai: JP-A 8-134037 (1996) (in Japanese)

\section{要 約}

\section{カルプロパミドによるいもち病菌のメラニン生合成 中間体の蓄積と光の作用点}

倉橋良雄，新木康夫，金原太郎

Rolf PONTZEN，山口 勇

カルプロパミド (ウィン®) はP. oryzaeや $V$. dahliaeな どの平面培養やいもち病菌の振とう培養での菌の色素沈着 を強く抑制した。そしてそれらの野生株の培養物の抽出に よって白色の結晶が単離された，薄層クロマト $R f 0.36$ 付 近のスポットから得られた白色結晶の化学分析值は既に報 告されているシタロンのデータとよく一致した。 カルプロ パミド $10 \mu \mathrm{g} / \mathrm{ml}$ を処理したそれらの培養物中には多量の シタロンと少量のバーメロンが蓄積したが，2-ハイドロキ シジュグロンは検出されなかった. P. oryzae のアルビノ変 異株 $\left(\mathrm{P}_{2}\right.$-alb) の振とう培養にシタロンを加えると速やかに 代謝され，その培養は薄い褐色となった。しかしその培養 にあらかじめカルプロパミドを加えるとシタロンはあまり 代謝されないで培地中に残った. P. oryzae のアルビノ変異 株 $\left(\mathrm{P}_{2}\right.$-alb) の平面培養の菌叢先端に局所処理したシタロン とバーメロンは黒色色素に変換されたがその着色はカルプ ロパミドによって阻害された。これらの試験結果はカルプ ロパミドが菌類メラニン生合成においてシタロン及びバー メロンの脱水反応を阻害することを示唆している. 